\title{
Regulation of heat-induced apoptosis by Mcl-1 degradation and its inhibition by Hsp70
}

\author{
AR Stankiewicz ${ }^{1}$, AM Livingstone ${ }^{1}$, N Mohseni $^{1}$ and DD Mosser ${ }^{*}, 1$
}

Cellular stress eliminates irreversibly damaged cells by initiating the intrinsic death pathway. Cell stress is sensed by pro- and antiapoptotic members of the Bcl-2 protein family, which regulate the release of apoptogenic factors, such as cytochrome $c$, from mitochondria. Exposure of cells to hyperthermia results in the activation of the proapoptotic Bcl-2 family protein Bax, which plays an essential role in cytochrome $c$ release. Heat directly affects Bax activity in vitro; however, antiapoptotic Bcl-2 family proteins, such as $\mathrm{Bcl}-\mathrm{xL}$, can suppress this activation, suggesting that a second heat-sensitive step must be breached before apoptosis ensues in cells exposed to hyperthermia. Here we show that heat shock causes the loss of Mcl-1 protein. Depletion of Noxa by short hairpin RNA protected cells from hyperthermia by preventing Mcl-1 degradation. Heat shock caused the dissociation of Noxa from Mcl-1, which allowed binding of the BH3-containing ubiquitin ligase Mule followed by Mcl-1 ubiquitination and degradation. Overexpression of $\mathrm{Hsp} 70$, which prevents heat-induced Bax activation, stabilized Mcl-1 protein levels in heat-shocked cells. This resulted from reduced Mule binding and ubiquitination as well as enhanced Mcl-1 expression compared with cells without Hsp70. Our results demonstrate that loss of Mcl-1 is a critical heat-sensitive step leading to Bax activation that is controlled by Hsp70.

Cell Death and Differentiation (2009) 16, 638-647; doi:10.1038/cdd.2008.189; published online 16 January 2009

Stress-induced cell death is controlled by pro- and antiapoptotic members of the Bcl-2 protein family. Interactions between these proteins regulate the release of cytochrome $c$ from mitochondria, which binds cytosolic Apaf-1 leading to its oligomerization into a caspase-activating complex called the apoptosome. Proteolytic processing of procaspase-3, by apoptosome-associated caspase- 9 , leads to its activation. This effector caspase cleaves specific proteins that ultimately result in cellular inactivation and apoptotic body formation. ${ }^{1}$ The release of cytochrome $c$ from mitochondria occurs through channels formed by oligomerization of the proapoptotic Bcl-2 family members Bax and Bak. ${ }^{2}$ This step is inhibited by the antiapoptotic Bcl-2 family members Bcl-2, $\mathrm{Bcl}-\mathrm{xL}, \mathrm{Mcl}-1$ and $\mathrm{A} 1{ }^{3}$ The ability of these proteins to suppress Bax/Bak activation is negatively regulated by proapoptotic BH3-only-containing Bcl-2 family members, of which there are eight in humans, including Noxa, Puma, Bid, Bim and Bad. The BH3-only proteins act as stress sensors, which when activated either by increased expression or posttranslational modification, suppress the ability of the antiapoptotic Bcl-2 family proteins to repress Bax and Bak. ${ }^{4}$ In addition to this indirect mechanism of Bax/Bak activation, some BH3-only proteins (Bim and Bid) are thought to act directly on Bax and Bak by promoting a conformational change necessary for mitochondrial membrane insertion (Bax) and oligomerization (Bax/Bak). ${ }^{5}$
Exposure of lymphoid cells to mild hyperthermia triggers apoptosis through Bax activation. ${ }^{6}$ Bax and Bak are essential for heat-induced apoptosis, as cells lacking both proteins do not release cytochrome $c$ when exposed to hyperthermia. ${ }^{7}$ Heating purified mitochondria or recombinant Bax in vitro can directly trigger the conformational change in Bax and Bak that leads to oligomerization and cytochrome $c$ release. However, the addition of cytosol or the cytosolic antiapoptotic protein $\mathrm{Bcl}-\mathrm{xL}$ inhibited heat-activated $\mathrm{Bax}$ and $\mathrm{Bak}^{7}$ indicating that a second heat-sensitive step must be breached before apoptosis ensues. In support of this, when cells are exposed to hyperthermia, maximal Bax activation and cytochrome $c$ release do not occur until several hours after the heated cells are returned to $37^{\circ} \mathrm{C}^{6}$ In this study, we sought to determine whether the inactivation of the antiapoptotic protein $\mathrm{Mcl}-1$ was responsible for this second heat-sensitive step. The rationale for this is that unlike $\mathrm{Bcl}-2$ and $\mathrm{Bcl}-\mathrm{xL}, \mathrm{Mcl}-1$ has a short halflife allowing rapid changes in protein levels in response to stress or survival signaling. ${ }^{8}$

$\mathrm{Mcl}-1$ is essential for the normal development of the immune system. It is often overexpressed in malignant cells including follicular lymphoma and multiple myeloma, in which antisense-mediated downregulation of $\mathrm{Mcl}-1$ was sufficient to induce apoptosis. ${ }^{9,10}$ The expression of Mcl-1 is transcriptionally controlled by growth factor and cytokine signaling pathways. Regulation of Mcl-1 function can occur through

\footnotetext{
${ }^{1}$ Department of Molecular and Cellular Biology, University of Guelph, Guelph, Ontario N1G 2W1, Canada

*Corresponding author: DD Mosser, Department of Molecular and Cellular Biology, University of Guelph, Guelph, Ontario N1G 2W1, Canada.

Tel: +519 8244120 ext 58059; Fax: + 519837 2075; E-mail: rmosser@uoguelph.ca

Keywords: Mcl-1; Noxa; Bax; Bim; Hsp70; hyperthermia

Abbreviations: CHAPS, 3-[(3-cholamidopropyl)dimethylammonio]-1-propane sulfonate hydrate; DEVDase, protease activity toward Ac-DEVD-AMC (N-acetyl-AspGlu-Val-Asp-(7-amino-4-methylcoumarin); EGS, ethylene glycol bis-(succinimidyl succinate); IP, immunoprecipitation; PBS, phosphate-buffered saline; SDS-PAGE, sodium dodecyl sulfate-polyacrylamide gel electrophoresis; shRNA, short hairpin RNA; UV, ultraviolet

Received 12.6.08; revised 01.12.08; accepted 02.12.08; ; Edited by J Silke; published online 16.1.09
} 
alternative splicing to produce an $\mathrm{Mcl}-1 \mathrm{~L}$ antiapoptotic isoform and a $\mathrm{BH} 3-o n l y ~ \mathrm{Mcl}-1 \mathrm{~S}$ proapoptotic isoform. ${ }^{11}$ Caspase cleavage within the $\mathrm{N}$-terminal domain can also generate a proapoptotic protein. ${ }^{10} \mathrm{Mcl}-1$ is eliminated by proteasomal degradation in response to genotoxic stress, and this loss of $\mathrm{Mcl}-1$ is essential for Bax/Bak oligomerization and caspase activation. $^{12} \mathrm{Mcl}-1$ is targeted for proteasomal degradation by the BH3-containing E3 ligase Mule (aka: Ureb1, Lasu1, HUWE1 and ARF-BP1). ${ }^{13}$ Removal of growth factor signaling can trigger Mcl-1 elimination through glycogen synthase kinase (GSK)-3-mediated phosphorylation of $\mathrm{Mcl}-1$ serine159. ${ }^{14} \mathrm{Mcl}-1$ function has also been shown to be regulated by JNK-catalyzed phosphorylation. ${ }^{15}$ Loss of $\mathrm{Mcl}-1$ promotes apoptosis by preventing the sequestration of proapoptotic $\mathrm{Bcl}-2$ family proteins Bak and Bim. ${ }^{16,17}$ The overexpression of Noxa displaces Bim from Mcl-1 and leads to the depletion of Mcl-1 protein. ${ }^{18,19} \mathrm{Bim}$, on the other hand, stabilizes $\mathrm{Mcl}-1$ by preventing its interaction with Mule. ${ }^{18,20}$

Here we demonstrate a role for $\mathrm{Mcl}-1$ in the regulation of heat-induced apoptosis. The reduction of Noxa protein levels by short hairpin RNA (shRNA) expression stabilized Mcl-1 and protected cells from heat-induced apoptosis. We found that hyperthermia reduced $\mathrm{Mcl}-1$ synthesis, stimulated Mule binding and ubiquitination as well as caspase cleavage of Mcl1. Overexpression of Hsp70 inhibited heat-induced apoptosis by preventing the loss of $\mathrm{Mcl}-1$. This occurred as a result of a combination of continued $\mathrm{Mcl}-1$ synthesis, inhibition of Mule binding and ubiquitination as well as prevention of caspase cleavage.

\section{Results}

Noxa depletion inhibits heat-induced apoptosis. The human acute lymphoblastic T-cell line PEER undergoes apoptosis during incubation at $37^{\circ} \mathrm{C}$ after exposure to hyperthermia. ${ }^{21}$ Overexpression of Hsp70 prevents heatinduced Bax activation, cytochrome $c$ release and caspase activation in these cells. ${ }^{6,22,23}$ To determine the events upstream of Bax activation that are induced by hyperthermia, we examined the role of the BH3-only protein Noxa in heatinduced apoptosis. For this, we produced PEER cell lines stably expressing a Noxa shRNA (clones N12, N14 and NG7) or an irrelevant shRNA (S13) using the pSUPER shRNA expression plasmid. In cells exposed to hyperthermia, Noxa protein levels decreased initially and then returned to higher than basal level by $6 \mathrm{~h}$ after the heatshock treatment (Figure 1a). In the Noxa shRNA cell lines, basal levels of Noxa were undetectable and the level at $6 \mathrm{~h}$ after heat shock was greatly reduced compared with the parental or control shRNA cell line. As Noxa has been shown to regulate $\mathrm{Mcl}-1$ levels we also examined the effect of hyperthermia on Mcl-1 in these cell lines. Heat shock caused a decrease in the levels of $\mathrm{Mcl}-1 \mathrm{~L}$ in both the parental and control shRNA cell line. In contrast, basal levels of $\mathrm{Mcl}-1$ were elevated in the Noxa shRNA cell lines and these levels were maintained in cells exposed to hyperthermia.

Depletion of Noxa therefore prevents the heat-induced loss of Mcl-1. To determine whether this confers increased heat resistance, cells were exposed to hyperthermia and assayed for protease activity toward Ac-DEVD-AMC ( $N$-acetyl-AspGlu-Val-Asp-(7-amino-4-methylcoumarin) (DEVDase activity) (Figure 1b) and scored for the presence of apoptotic cells (Figure 1c). Compared with the control shRNA cell line, both caspase activation and the apoptotic cell count were reduced in the Noxa shRNA cell lines. Noxa has been shown to play a role in ultraviolet (UV)-induced apoptosis, as Noxa-deficient mouse fibroblasts are resistant to UV treatment. ${ }^{24}$ The Noxa shRNA cell lines also showed reduced caspase activation in response to UV exposure (Figure 1d). Long-term survival assays demonstrate enhanced resistance to UV or hyperthermia in Noxa-depleted cells (Figure 1e). Noxa reduction therefore does not simply delay apoptosis in the stressed cells.

Noxa depletion inhibits heat-induced Bax activation. Bax activation proceeds through an initial priming step that alters its conformation, allowing mitochondrial membrane insertion followed by oligomerization, producing channels that permit the release of cytochrome $c$. The antiapoptotic $\mathrm{Bcl}-2$ family proteins negatively regulate this oligomerization step. Exposure of cells to hyperthermia induces a conformational change in Bax that permits its translocation and oligomerization in the mitochondrial outer membrane. ${ }^{6}$ We tested whether Noxa depletion could affect either of these steps in heat-induced Bax activation. The stress-induced conformational change in Bax was assessed by immunoprecipitation (IP) with an antibody specific for the active form of Bax followed by western blotting. Bax oligomerization was measured by treating extracts with the chemical cross-linker ethylene glycol bis-(succinimidyl succinate) (EGS) followed by western blotting. Depletion of Noxa significantly reduced Bax activation (Figure 2a) and oligomerization (Figure 2b) in cells exposed to hyperthermia.

Willis et al. ${ }^{17}$ demonstrated that the binding of Noxa to $\mathrm{Mcl}-1$ caused the displacement of Bak leading to Mcl-1 degradation. We therefore examined the influence of Noxa expression on the interaction of Mcl-1 with Bax and Bak in cells exposed to hyperthermia. Mcl-1 was immunoprecipitated from control and heat-shocked control shRNA- and Noxa shRNA-expressing cells followed by western blotting (Figure 2c). Exposure to hyperthermia altered the composition of Mcl-1 complexes. Increased levels of Bax and BimEL were found associated with Mcl-1 immediately after the heat-shock exposure, and this coincided with a reduced association of Noxa with $\mathrm{Mcl}-1$. The increased $\mathrm{Mcl}-1 / \mathrm{Bax}$ association was only transient with the release of Bax occurring at the same time as Bax oligomerization was taking place. Noxa reassociated with Mcl-1 during post-heat-shock incubation at $37^{\circ} \mathrm{C}$ with high levels of association occurring after $6 \mathrm{~h}$ when the total levels of Noxa were enhanced. The association of Bak and BimEL with Mcl-1 decreased over this time period. In contrast to the control shRNA-expressing cells, when the Noxa shRNAexpressing cells were exposed to heat shock, Mcl-1 maintained higher levels of association with Bak and BimEL.

Hsp70 overexpression prevents the loss of Mcl-1 in heat-shocked cells. As Hsp70 is a potent suppressor of Bax activation, ${ }^{6}$ we next examined the effect of Hsp70 

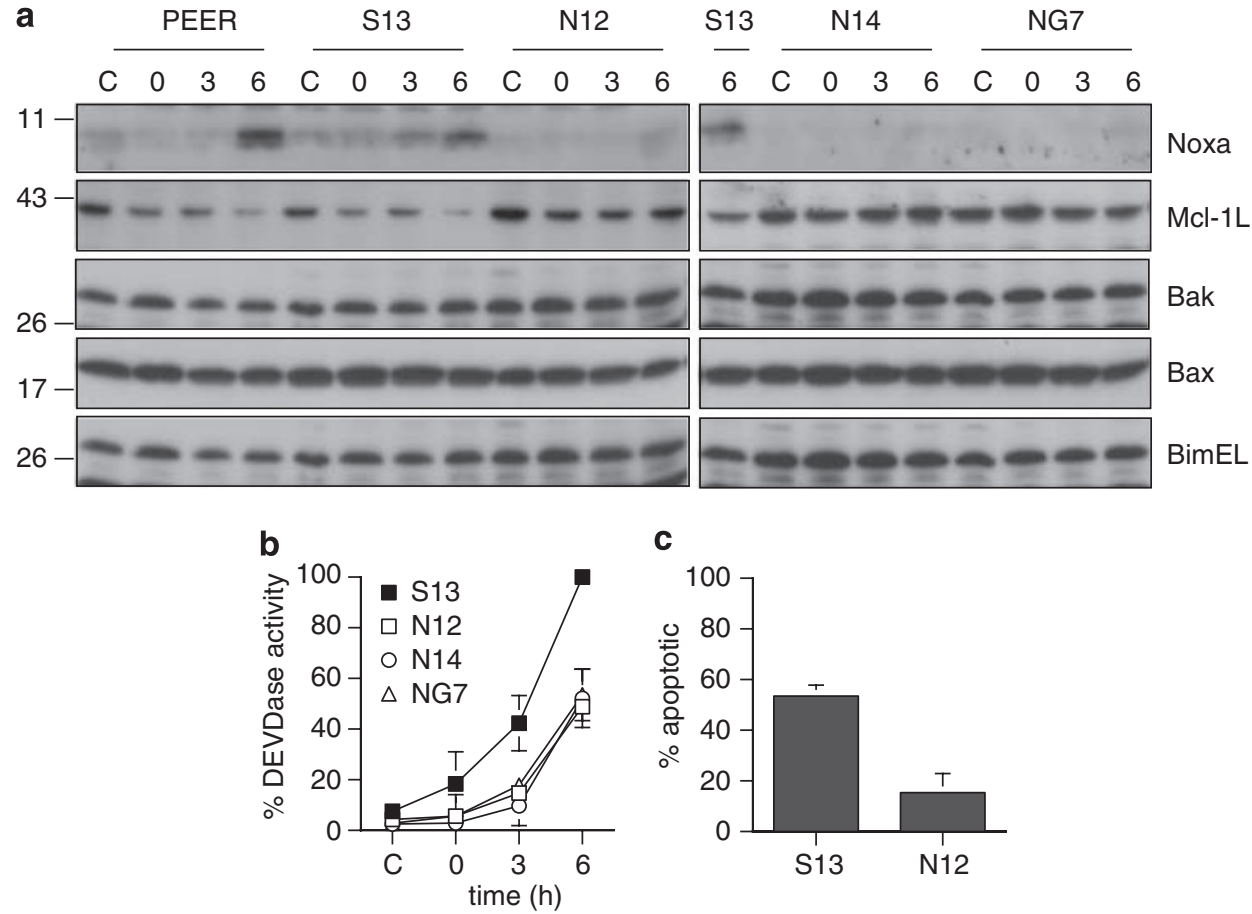

c
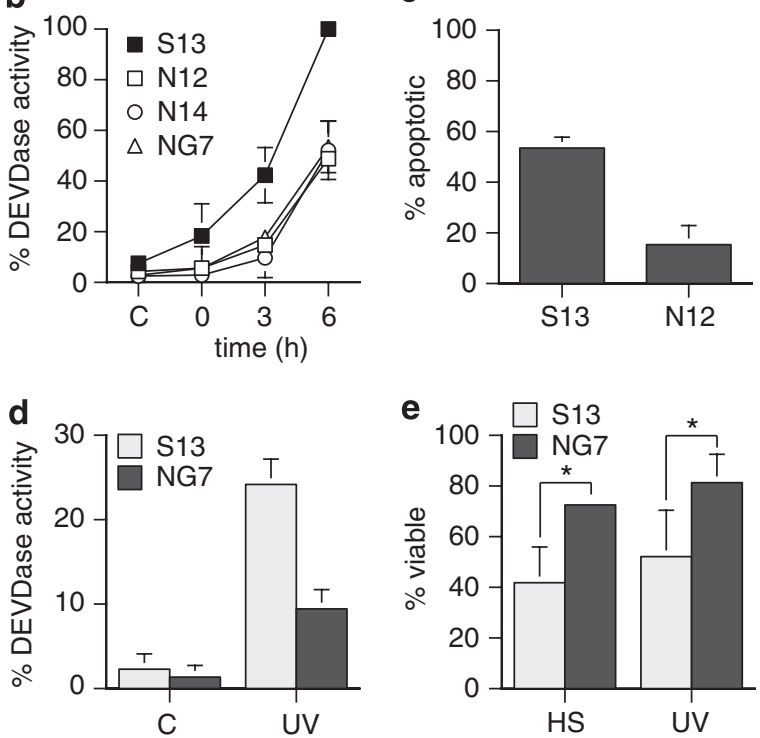

Figure 1 Depletion of Noxa by RNA interference prevents heat-induced apoptosis. (a) Expression of Noxa shRNA reduces basal Noxa protein levels and prevents the heat-induced expression of Noxa. Parental PEER, control shRNA clone S13 and Noxa shRNA clones N12, N14 and NG7 were either untreated (C) or subjected to hyperthermia for $1 \mathrm{~h}$ at $43^{\circ} \mathrm{C}$ and collected immediately (0) or after an additional incubation at $37^{\circ} \mathrm{C}$ for 3 or $6 \mathrm{~h}$. The abundance of Noxa, Mcl-1, Bak, Bax and Bim was examined in total cell lysates by western blotting. (b) Expression of Noxa shRNA reduces hyperthermia-induced caspase-3 activity. DEVDase activity was examined in lysates of cells from clones S13, N12, N14 and NG7 that were treated as in (a). DEVDase activity is plotted relative to the maximum value (mean \pm S.D., $N=3$ ). (c) Expression of Noxa shRNA reduces hyperthermia-induced apoptosis. The $S 13$ and N12 clones were exposed to $43^{\circ} \mathrm{C}$ for $1 \mathrm{~h}$ and then incubated at $37^{\circ} \mathrm{C}$ for $6 \mathrm{~h}$. Cell nuclei were stained with acridine orange and the number of apoptotic and viable cells was counted (mean \pm S.D., $N=2$ ). (d) Expression of Noxa shRNA reduces UV-induced caspase-3 activation. DEVDase activity was measured in lysates of $S 13$ and NG7 cell clones that were exposed to UV $\left(40 \mathrm{~kJ} / \mathrm{m}^{2}\right)$ followed by a $6 \mathrm{~h}$ incubation at $37^{\circ} \mathrm{C}$ (mean \pm S.D., $N=3$ ). (e) Expression of Noxa shRNA increases long-term viability of cells exposed to UV or hyperthermia. S13 and NG7 clones were exposed to $43^{\circ} \mathrm{C}$ for $1 \mathrm{~h}$ or UV irradiation at $40 \mathrm{~kJ} / \mathrm{m}^{2}$ and then incubated at $37^{\circ} \mathrm{C}$ for $72 \mathrm{~h}$. Viability is shown as the mean percentage $( \pm S . D ., N=3)$ of values for treated cells relative to untreated cells $\left({ }^{\star} P<0.05\right)$

overexpression on $\mathrm{Mcl}-1$ in cells exposed to hyperthermia. For this, we used a stably transfected PEER cell line with tetracycline-regulated expression of $\mathrm{Hsp} 70 .^{23}$ The loss of $\mathrm{Mcl}-1$ that was seen when the non-induced cells (OFF) were exposed to hyperthermia was prevented when Hsp70 was overexpressed in the induced cells (ON) (Figure 3a). Loss of Mcl-1 occurred at approximately the same time as Bax activation and caspase-3 processing in the non-induced cells. Mcl-1 is subject to caspase-3-mediated cleavage at Asp127 generating a $28-\mathrm{kDa}$ fragment. ${ }^{25}$ Hsp70 overexpression, which prevents caspase-3 activation in heatshocked cells, ${ }^{22}$ prevented both the loss of $\mathrm{Mcl}-1 \mathrm{~L}$ and the generation of the $\mathrm{Mcl}-1$ cleavage product. Noxa protein levels were reduced immediately after exposure to hyperthermia and then increased to a higher-than-basal level during incubation at $37^{\circ} \mathrm{C}$. This occurred in both the non-induced and induced cells; however, the initial loss was somewhat less in the Hsp70-expressing cells.

Heat shock is a potent activator of the stress kinase JNK, which has been shown to phosphorylate and inhibit the activity of $\mathrm{Mcl}-1 .{ }^{15}$ As Hsp70 is able to suppress heat-induced JNK activation, ${ }^{22,26}$ we examined whether the inhibition of JNK by treatment with the specific inhibitor SP600125 could also prevent the loss of $\mathrm{Mcl}-1$ in heat-shocked cells. Similar to Hsp70 overexpression, SP600125-treated cells maintained high levels of $\mathrm{Mcl}-1$ following exposure to hyperthermia 
a

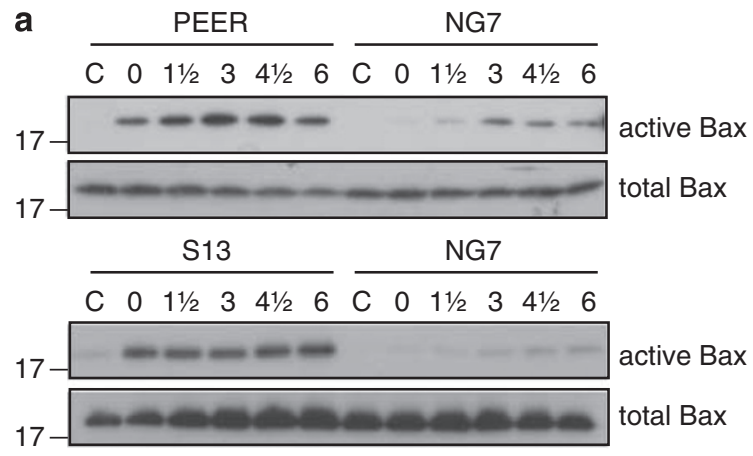

C

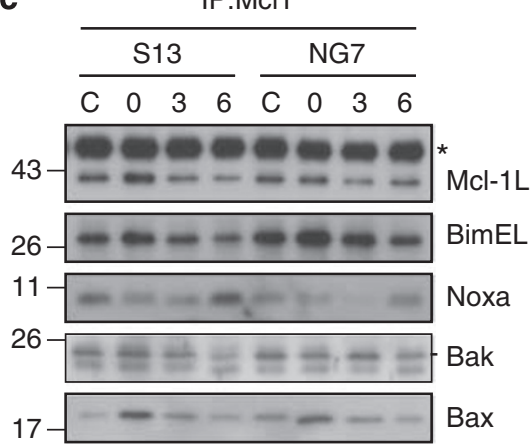

b
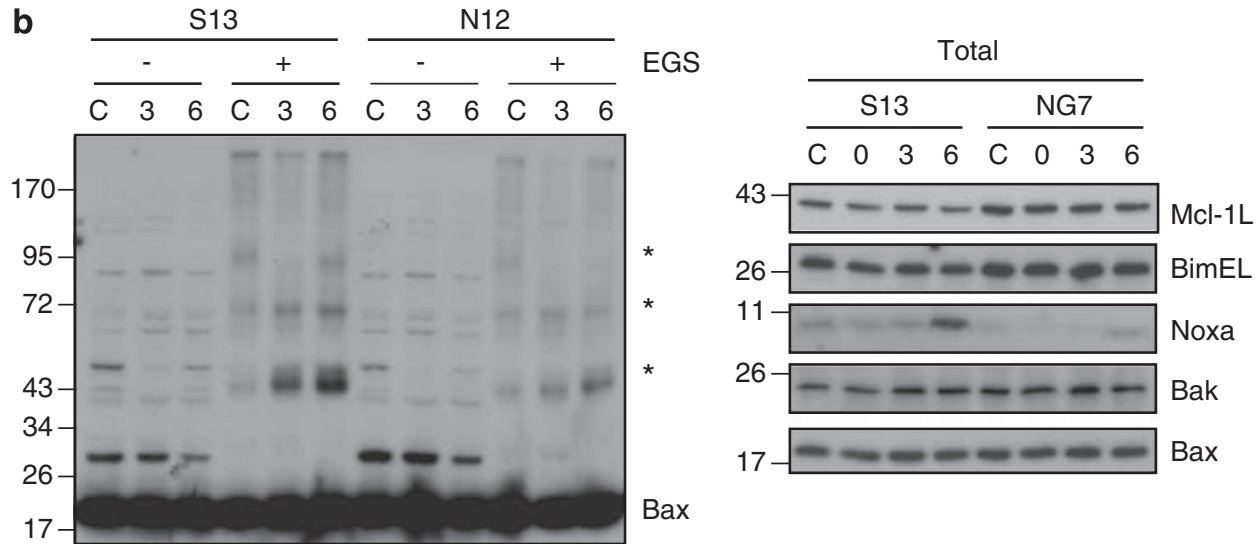

Figure 2 Noxa depletion inhibits heat-induced Bax activation and oligomerization resulting in Mcl-1 stabilization and increased association of Bim and Bak with Mcl-1. (a) Parental (PEER), control shRNA (S13)- and Noxa shRNA (NG7)-expressing cells were exposed to $43^{\circ} \mathrm{C}$ for $1 \mathrm{~h}$ and then incubated at $37^{\circ} \mathrm{C}$ for the indicated periods of time (h). Bax activation was examined by immunoprecipitation with a conformation-specific antibody. The amount of active Bax and total Bax (total lysate) was analyzed by western blotting with an anti-Bax antibody. (b) Control shRNA (S13)- and Noxa shRNA (N12)-expressing cells were exposed to $43^{\circ} \mathrm{C}$ for $1 \mathrm{~h}$ and then incubated for 3 or $6 \mathrm{~h}$ at $37^{\circ} \mathrm{C}$. Cells were lysed in CHAPS lysis buffer and treated with EGS to cross-link interacting proteins. Cross-linked (EGS + ) and non-treated samples (EGS-) were analyzed by SDS-PAGE and by immunoblotting with an anti-Bax antibody. Asterisks indicate multimeric forms of Bax. (c) Control shRNA (S13)- and Noxa shRNA (NG7)-expressing cells were exposed to $43^{\circ} \mathrm{C}$ for $1 \mathrm{~h}$ and then incubated for 3 or $6 \mathrm{~h}$ at $37^{\circ} \mathrm{C}$. Cells were lysed in CHAPS lysis buffer and equivalent amounts of protein from each lysate were used for immunoprecipitation with an anti-Mcl-1 antibody. The immunoprecipitated proteins and total extracts were analyzed by SDS-PAGE and by immunoblotting with anti-Mcl-1, Bim, Noxa, Bak and Bax antibodies ( $\left.{ }^{*} \operatorname{lgG}\right)$

(Figure 3b). SP600125 treatment delayed JNK phosphorylation and inhibited caspase-3 activation. These results suggest that the inhibition of Mcl-1 degradation by Hsp70 may be in part attributable to its ability to inhibit JNK activation, although the role of JNK phosphorylation in the regulation of Mcl-1 protein function in heat-shocked cells remains to be determined.

We also examined whether Hsp70 overexpression could prevent Mcl-1 degradation in cells exposed to UV. Exposure to UV resulted in the loss of $\mathrm{Mcl}-1$ protein in both the noninduced and the Hsp70-expressing cells (Figure 3c). Hsp70 overexpression was unable to prevent caspase-3 activation and apoptosis in the UV-exposed cells. This is in contrast to Noxa suppression, which was able to protect cells from either hyperthermia or UV exposure (Figure 1e).

Heat shock causes increased ubiquitination and caspase cleavage of Mcl-1. To determine whether the loss of $\mathrm{Mcl}-1$ was due to proteasomal degradation, we examined $\mathrm{Mcl}-1$ protein levels in cells exposed to hyperthermia in the presence of the proteasomal inhibitor
MG132 (Figure 4a). Treatment with MG132 increased the basal level of Mcl-1 and prevented the loss of Mcl-1 after exposure to heat shock, but did not prevent the generation of the caspase-3-cleaved $\mathrm{Mcl}-1$ fragment. These results show that the loss of Mcl-1L in heat-shocked cells is due to both proteasomal and caspase-mediated degradation. Interestingly, levels of BimEL were also reduced as apoptosis progressed but this was prevented by MG132, illustrating that BimEL is also subject to proteasomal degradation. ${ }^{27}$ This effect of proteasomal inhibition on BimEL accumulation may explain why caspase-3 activation occurred when the Hsp70-expressing cells were treated with MG132.

Exposure to heat shock caused the accumulation of ubiquitinated proteins; however, this accumulation did not occur in cells overexpressing Hsp70 (Figure 4a). To determine whether ubiquitinated $\mathrm{Mcl}-1$ accumulated in cells exposed to hyperthermia, we immunoprecipitated $\mathrm{Mcl}-1$ under denaturing conditions and probed for ubiquitin. A progressive increase in the amount of polyubiquitinated $\mathrm{Mcl}-1$ was seen in the non-induced cells exposed to heat 

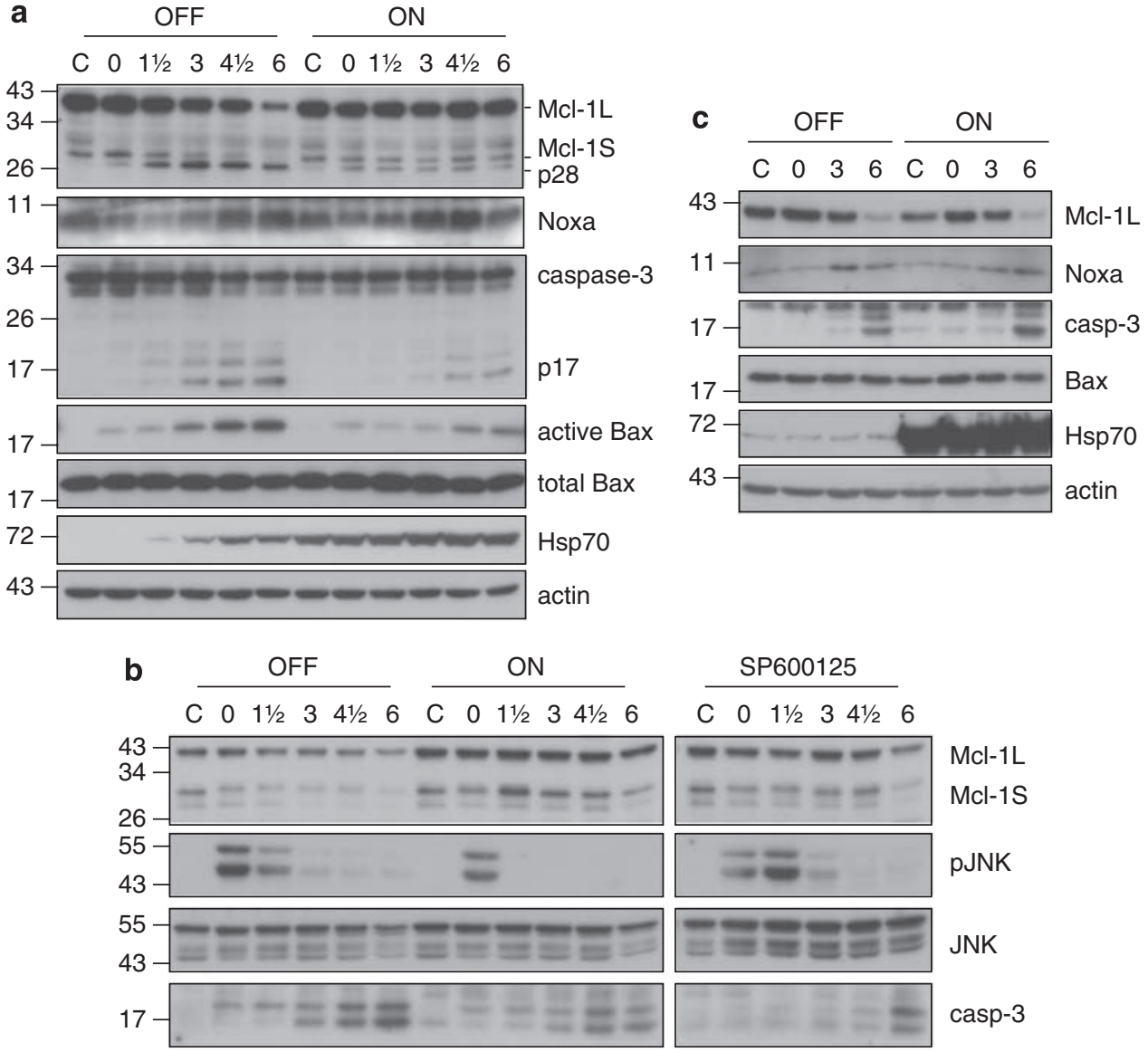

Figure 3 Hsp70 overexpression prevents heat-induced Mcl-1 degradation. (a) PErTA70 cells with tetracycline-regulated expression of Hsp70 (OFF = non-induced, $\mathrm{ON}=$ induced) were exposed to $43^{\circ} \mathrm{C}$ for $1 \mathrm{~h}$ and then incubated at $37^{\circ} \mathrm{C}$ for the indicated periods of time $(\mathrm{h})$. Lysates containing equivalent amounts of protein were separated by SDS-PAGE and the levels of Mcl-1, Noxa, caspase-3, Bax, Hsp70 and actin were detected by immunoblotting. Active Bax was measured by immunoprecipitation with a conformation-specific anti-Bax antibody followed by western blotting. (b) JNK inhibition prevents Mcl-1 degradation. PErTA70 cells that were either non-induced, induced to express Hsp70 or treated with the JNK inhibitor SP600125 $(20 \mu \mathrm{M})$ were exposed to $43^{\circ} \mathrm{C}$ for $1 \mathrm{~h}$ and then incubated at $37^{\circ} \mathrm{C}$ for the indicated periods of time (h). Lysates containing equivalent amounts of protein were separated by SDS-PAGE and the levels of Mcl-1, pJNK, JNK and caspase-3 (p17 fragment) were detected by immunoblotting. (c) Hsp70 overexpression does not prevent Mcl-1 degradation in cells exposed to UV. Non-induced and induced PErTA70 cells were exposed to UV $\left(40 \mathrm{~kJ} / \mathrm{m}^{2}\right)$ followed by incubation at $37^{\circ} \mathrm{C}$ for the times indicated (h). Lysates were separated by SDS-PAGE and the levels of Mcl-1, Noxa, caspase-3 (p17 fragment), Bax, Hsp70 and actin were detected by immunoblotting

shock but not in cells overexpressing Hsp70 (Figure 4b). We next examined whether the rate of $\mathrm{Mcl}-1$ protein turnover was affected by heat-shock treatment. For this experiment, cells were exposed to hyperthermia and then incubated at $37^{\circ} \mathrm{C}$ for 3 or $6 \mathrm{~h}$ in the presence of cycloheximide. The pan-caspase inhibitor ZVAD was included to allow the measurement of protein turnover in the absence of caspase cleavage. The half-life of $\mathrm{Mcl}-1$ at $37^{\circ} \mathrm{C}$ was approximately $3 \mathrm{~h}$ in both the non-induced and the induced cells (Figure 4c), similar to what has been reported in other cell lines. ${ }^{28}$ Some loss of Mcl-1 occurred during the $1 \mathrm{~h}$ exposure to $43^{\circ} \mathrm{C}$ in the absence of cycloheximide (compare HS: $\mathrm{C}$ and 0 ). When the cells were then returned to $37^{\circ} \mathrm{C}$ and incubated with cycloheximide the rate of Mcl-1 turnover was unaltered in the Hsp70-expressing cells; however, in the non-induced cells, the loss of Mcl-1 was delayed. This is likely due to the excessive load of misfolded and ubiquitinated proteins in the non-induced cells. The ability of Hsp70 to assist in the chaperoning of ubiquitinated proteins to the proteasome ${ }^{29}$ allowed for the efficient clearance of ubiquitinated $\mathrm{Mcl}-1$. In the absence of new protein synthesis, actin was also depleted after heat shock in the Hsp70expressing cells but not in the non-induced cells, illustrating the effect of Hsp70 overexpression on the clearance of ubiquitinated substrates. When cells were incubated at $37^{\circ} \mathrm{C}$ after heat shock in the absence of cycloheximide, but in the presence of $\mathrm{ZVAD}, \mathrm{Mcl}-1$ was still lost from the non-induced cells but not from the Hsp70-expressing cells, indicating that heat-shock treatment reduced the rate of new $\mathrm{Mcl}-1$ synthesis in the non-induced cells but not in the cells expressing Hsp70. Hsp70 has been shown to provide transcriptional and translational tolerance to cells exposed to hyperthermia. ${ }^{30}$ Altogether, these results show that the loss of $\mathrm{Mcl}-1$ in heatshocked cells is due to the combination of reduced synthesis, ubiquitination/proteasomal degradation and caspase cleavage. Each of these effects is suppressed in cells expressing Hsp70, resulting in the maintenance of Mcl-1 levels. 
a

\begin{tabular}{|c|c|}
\hline OFF & DN \\
\hline MG132 & MG132 \\
\hline
\end{tabular}
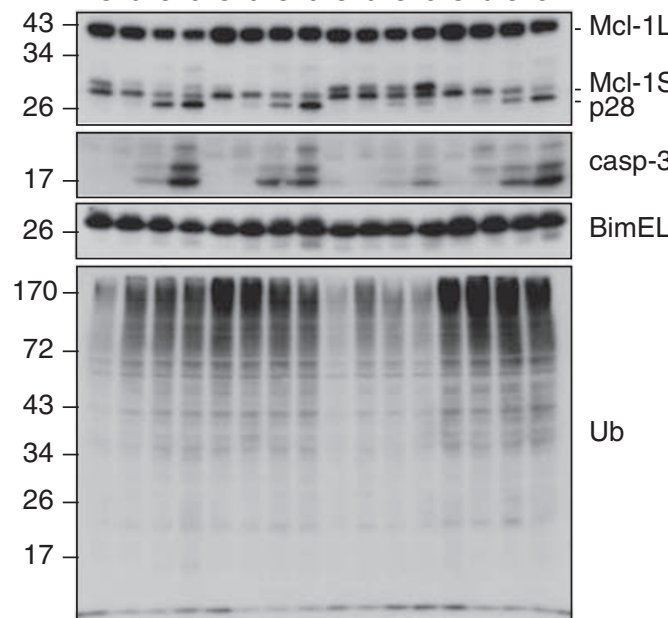

b

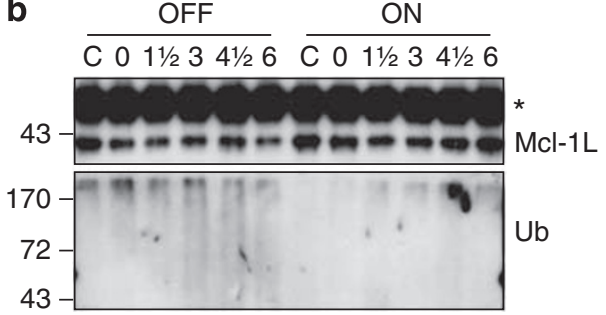

c

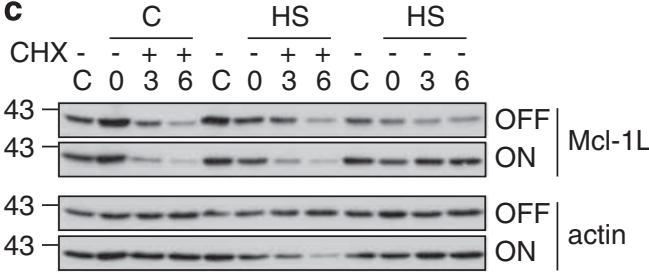

Figure $4 \mathrm{Hsp70}$ overexpression prevents heat-induced Mcl-1 ubiquitination. (a) Exposure of cells to the proteasome inhibitor MG132 prevents the heat-induced loss of Mcl-1L. Non-induced and induced PErTA70 cells were treated with $10 \mu \mathrm{M} \mathrm{MG132}$ and exposed to $43^{\circ} \mathrm{C}$ for $1 \mathrm{~h}$ and then incubated for 0,3 or $6 \mathrm{~h}$ at $37^{\circ} \mathrm{C}$. Lysates containing equivalent amounts of protein were separated by SDS-PAGE and the levels of Mcl-1, caspase-3 (p17 fragment), Bim and ubiquitin (Ub) were detected by immunoblotting. (b) Accumulation of ubiquitinated Mcl-1. PErTA70 cells were exposed to hyperthermia $\left(43^{\circ} \mathrm{C}\right.$ for $\left.1 \mathrm{~h}\right)$ and incubated at $37^{\circ} \mathrm{C}$ for the indicated periods of time (h). Cells were lysed in denaturing IP buffer and equivalent amounts of protein from each lysate were used for immunoprecipitation with an anti-Mcl-1 antibody. The immunoprecipitated proteins were separated by SDS-PAGE and levels of Mcl-1 and ubiquitinated Mcl-1 (Ub) were detected by immunoblotting (*IgG). (c) Measurement of Mcl-1 turnover. PErTA70 cells were incubated with $10 \mu \mathrm{M} z V A D$ for $30 \mathrm{~min}$ and then exposed to $43^{\circ} \mathrm{C}$ for $1 \mathrm{~h}$. Cells were either collected immediately (0) or incubated at $37^{\circ} \mathrm{C}$ for 3 or $6 \mathrm{~h}$ in the presence of $200 \mu \mathrm{g} / \mathrm{ml}$ cycloheximide. Lysates containing equivalent amounts of protein were separated by SDS-PAGE and the levels of Mcl-1 and actin were detected by immunoblotting

Hsp70 prevents the association of Mule with Mcl-1. We next examined the effect of Hsp70 overexpression on the composition of $\mathrm{Mcl}-1$ complexes in cells exposed to hyperthermia. Mcl-1 was immunoprecipitated from control and heat-shocked cells, and lysates were probed for the presence of Noxa, Bim, Bax and Bak (Figure 5a). Noxa was found to be associated with Mcl-1 in non-stressed cells; however, this complex was disrupted in cells exposed to hyperthermia. Reformation of this complex occurred following the resynthesis of Noxa. Cells expressing Hsp70 showed a similar pattern except that Noxa reassociated with Mcl-1 earlier reflecting the earlier increase in total Noxa levels. The association of Bak with Mcl-1 steadily decreased after heat shock. Although Bax initially showed increased binding to $\mathrm{Mcl}-1$ immediately after exposure to hyperthermia, this association was only transient. Interestingly, cells expressing Hsp70 had higher levels of Bax and Bak bound to $\mathrm{Mcl}-1$, and exposure to heat shock did not result in an increased binding of $\mathrm{Bax}$ to $\mathrm{Mcl}-1$ as it did in the non-induced cells. This indicates that Hsp70 might help sequester activated Bax through Mcl-1 binding in control cells and also inhibit the heat-induced conformational change in Bax. Nevertheless, the interaction of $\mathrm{Mcl}-1$ with Bax was transient with the released Bax forming oligomers in the non-induced cells but not in the Hsp70-expressing cells. ${ }^{6}$

As the unligated form of Mcl-1 is a target for Mule binding, ${ }^{20}$ we next asked whether heat-induced disruption of the complex containing Mcl-1 and Noxa resulted in increased binding of Mule to $\mathrm{Mcl}-1$. This was examined immediately after exposure of cells to hyperthermia. Immunoprecipitation of
Mcl-1 under non-denaturing conditions, to probe for interacting proteins, showed that heat shock increased the association of Mule with $\mathrm{Mcl}-1$ and that this was inhibited in cells expressing Hsp70 (Figure 5b). We also examined these immunoprecipitates for the presence of Hsc70 and Hsp70. Hsc70 was associated with Mcl-1 in heat-shocked cells, whereas Hsp70 was bound in both the control and heatshocked cells in the Hsp70-expressing cells. To test the specificity of these interactions, we performed IPs in the presence of excess Mcl-1-specific peptide and an irrelevant peptide (Figure $5 \mathrm{c}$ ). The presence of excess Mcl-1 peptide prevented Mcl-1 IP, resulting in a loss of the Mule, Noxa and Hsc70 signals. Excess of Bax peptide did not prevent Mcl-1 IP and did not affect the co-IP of Mule or Noxa with Mcl-1, although the signal for $\mathrm{Hsc} 70$ was somewhat reduced in the presence of excess Bax peptide. Co-IP of $\mathrm{Hsp} 70$ with $\mathrm{Mcl}-1$, using extracts from the Hsp70-expressing cells, could not be competed by the presence of excess $\mathrm{Mcl}-1$ peptide, suggesting that this interaction may not be Mcl-1 specific (data not shown).

In summary, these results support a model in which heat shock promotes Bax activation through depletion of $\mathrm{Mcl}-1$ (Figure $5 \mathrm{~d}$ ). Synthesis of Mcl-1 was inhibited in cells exposed to hyperthermia. Mule binding and subsequent ubiquitination inactivated the pre-existing Mcl-1. Depletion of $\mathrm{Mcl}-1$ resulted in Bax activation, and the subsequent caspase activation aided in the complete destruction of $\mathrm{Mcl}-1$. In the presence of excess Hsp70, ubiquitinated Mcl-1 did not accumulate and the heat-induced inhibition of $\mathrm{Mcl}-1$ synthesis was averted as well, leading to the stabilization of Mcl-1 protein levels. 
a

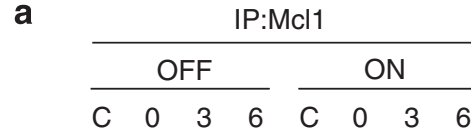
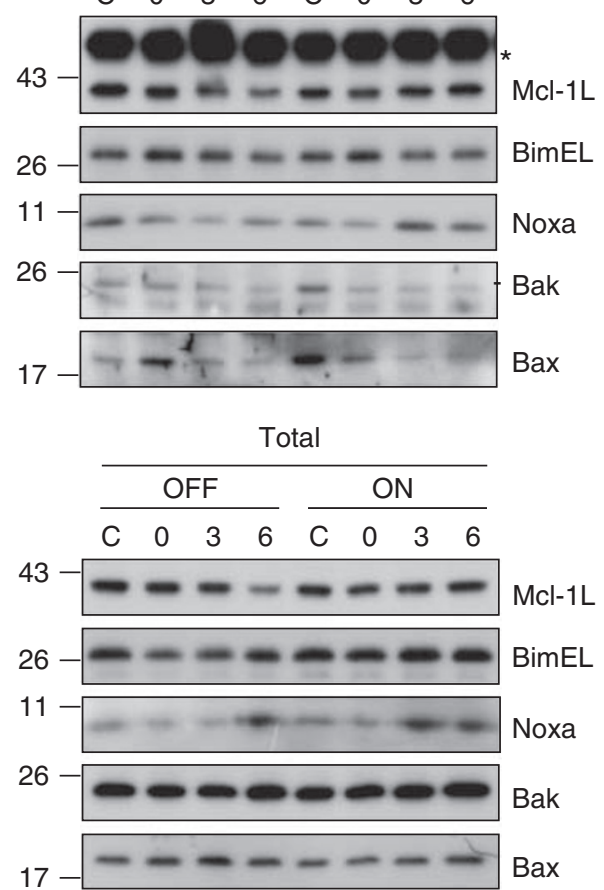
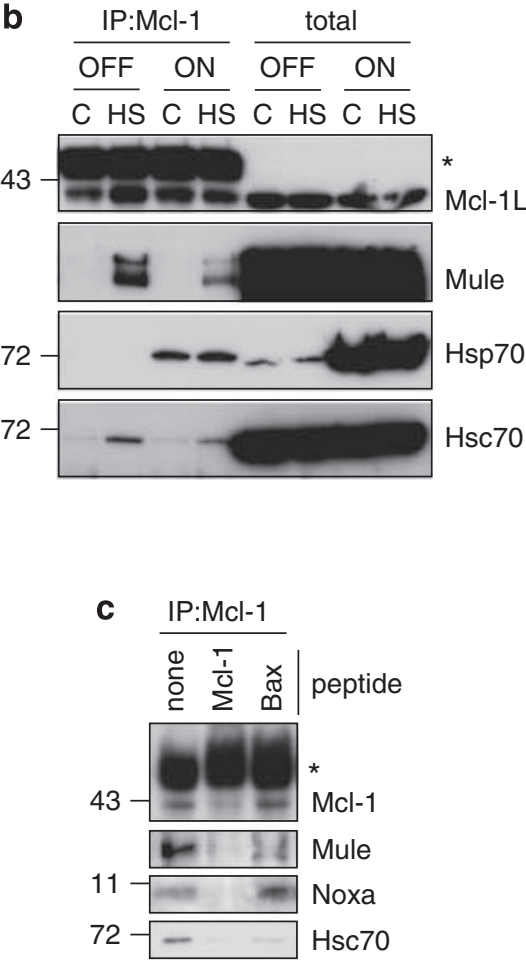

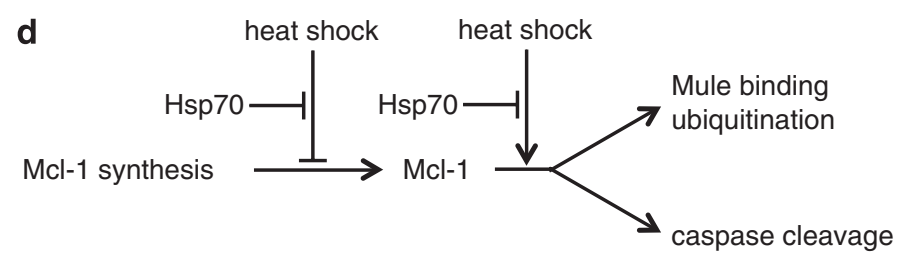

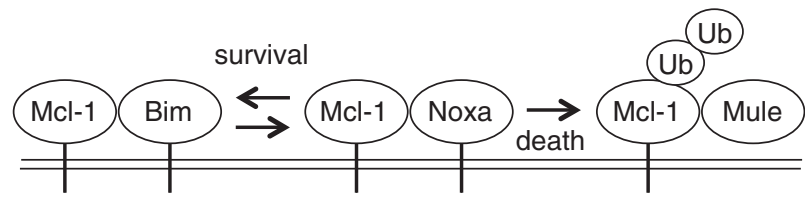

Figure 5 Heat-induced disruption of Noxa from Mcl-1 leads to Mule binding, ubiquitination and degradation of Mcl-1. (a) PErTA70 cells were exposed to $43^{\circ} \mathrm{C}$ for $1 \mathrm{~h}$ and then incubated for 3 or $6 \mathrm{~h}$ at $37^{\circ} \mathrm{C}$. Cells were lysed in CHAPS lysis buffer and equivalent amounts of protein from each lysate were used for immunoprecipitation with an antiMcl-1 antibody. The immunoprecipitated proteins and total extracts were analyzed by SDS-PAGE and by immunoblotting with anti-Mcl-1, Bim, Noxa, Bak and Bax antibodies $\left({ }^{*} \mathrm{IgG}\right)$. (b) Control and heat-shocked $\left(43^{\circ} \mathrm{C}\right.$ for $1 \mathrm{~h}$ ) cells were lysed in CHAPS buffer and immunoprecipitated with anti-Mcl-1 antibody. The immunoprecipitated proteins and total extracts were analyzed by SDS-PAGE and immunoblotting with anti-Mcl-1, Mule, Hsc70 and Hsp70 antibodies. (c) Extracts from non-induced cells that were exposed to heat shock $\left(43^{\circ} \mathrm{C}\right.$ for $\left.1 \mathrm{~h}\right)$ were immunoprecipitated in the presence of a fivefold excess of an antigen-specific peptide (Mcl-1) or a nonspecific peptide (Bax). The immunoprecipitated proteins were analyzed by SDS-PAGE and immunoblotting with anti-Mcl-1, Mule, Noxa and Hsc70 antibodies ( ${ }^{*}$ lgG). (d) Model showing Mcl-1 synthesis and the effect of hyperthermia on Mcl-1 protein levels (see text for details)

\section{Discussion}

Understanding the mechanisms controlling stress-induced apoptosis is central to the understanding of how cells and organisms respond to their environment. A universally conserved mechanism for providing adaptive tolerance to hyperthermia is the heat-shock response. ${ }^{31}$ Stress-induced expression of the heat-shock proteins, which assist in protein conformational homeostasis, allows cells to survive under conditions that threaten the folding integrity of cellular proteins, which can occur during environmental insult, disease and aging. ${ }^{32}$ The major heat-inducible protein, Hsp70, plays an important role in stress resistance. ${ }^{31}$ How hyperthermia causes apoptosis and how Hsp70 suppresses this are not clear. Earlier, we have shown that the exposure of lymphoid cells to hyperthermia leads to the activation of Bax, a key step in the mitochondrial apoptotic pathway, and that Hsp70 overexpression inhibits heat-induced Bax activation and cell death. ${ }^{6}$ In vitro experiments have shown that conditions affecting protein stability, such as non-ionic 
detergents, altered $\mathrm{pH}$ or hyperthermia can also activate Bax. Whether these physical treatments participate in the direct activation of Bax in vivo is not known. Nevertheless, the ability of heat-treated Bax to permeabilize mitochondria in vitro can be inhibited by the inclusion of cytosol or purified Bcl-xL. ${ }^{7}$ This suggests that a second heat-sensitive step, involving an antiapoptotic member of the $\mathrm{Bcl}-2$ family, must be breached for hyperthermia to trigger Bax activation. Our results reveal that this second step is the degradation of $\mathrm{Mcl}-1$, which allows Bax oligomerization to occur.

Elimination of $\mathrm{Mcl}-1$ is an essential step in the initiation of apoptosis in response to DNA damage or growth factor withdrawal. ${ }^{14,33,34}$ Our results indicate that loss of Mcl-1 is also essential for apoptosis to proceed in response to proteotoxic stress. For both genotoxic stress and growth factor withdrawal, the rapid loss of Mcl-1 was due to the relatively short half-life of the $\mathrm{Mcl}-1$ protein. Exposure to UV or etoposide resulted in an inhibition of $\mathrm{Mcl}-1 \mathrm{mRNA}$ and protein synthesis, such that apoptosis ensued when the existing pool of $\mathrm{Mcl}-1$ turned over without any affect on the rate of this turnover. ${ }^{34}$ The inhibitory effect of hyperthermia on protein synthesis also contributed to the loss of $\mathrm{Mcl}-1$ in heat-shocked cells. Hsp70 overexpression, which is capable of providing translational thermotolerance, ${ }^{30}$ allowed for the continued replacement of the degraded $\mathrm{Mcl}-1$ by new synthesis.

Mcl-1 protein turnover is regulated by phosphorylation. Following IL-3 deprivation, the loss of $\mathrm{Mcl}-1$ was attributable to an increased rate of $\mathrm{Mcl}-1$ protein degradation. ${ }^{14}$ This increase in proteasomal degradation was regulated by $\mathrm{Mcl}-1$ phosphorylation by GSK-3, which was activated as a result of reduced Akt phosphorylation in growth factor-deprived cells. Phosphorylation of Mcl-1 serine-159 by GSK-3 was required for $\mathrm{Mcl}-1$ ubiquitination and proteasomal degradation. Ubiquitination of $\mathrm{Mcl}-1$ is mediated by the E3 ligase Mule (ARF-BP1), which interacts with $\mathrm{Mcl}-1$ through its $\mathrm{BH} 3$ domain. ${ }^{13}$ Our results show that heat shock caused an enhanced binding of Mule to Mcl-1 followed by the accumulation of ubiquitinated Mcl-1 and that both of these events were inhibited in cells expressing Hsp70. Whether the interaction of Mule with Mcl-1 is also controlled by $\mathrm{Mcl}-1$ phosphorylation is not known; however, this is a common mechanism of substrate recognition by the HECT E3 ligases. ${ }^{35}$ Interestingly, GSK-3 requires a priming phosphorylation to recognize a phosphorylatable target residue. In Mcl-1, this priming site, threonine-163, has been shown to be phosphorylated by JNK in response to oxidative stress. ${ }^{15} \mathrm{JNK}$ is activated by proteotoxic stress and this activation can be suppressed by Hsp70 overexpression. ${ }^{22,26}$ We found that suppression of JNK with SP600125 was as effective as Hsp70 overexpression in the prevention of Mcl-1 turnover in heat-stressed cells. It will be interesting to determine whether JNK-mediated phosphorylation controls the ability of Mcl-1 to interact with Mule.

Noxa appears to play a role in the regulation of $\mathrm{Mcl}-1$ stability. Overexpression of Noxa results in the depletion of $\mathrm{Mcl}-1,{ }^{18}$ suggesting that Noxa binding targets Mcl-1 for degradation. This is supported by our finding that Mcl-1 is present in a complex with Noxa in non-stressed cells and that depletion of Noxa by shRNA increased $\mathrm{Mcl}-1$ protein levels. Heat shock appears to directly displace Noxa from Mcl-1, allowing Mule binding and ubiquitination to occur. Displace- ment of Noxa from Mcl-1 also resulted in an increased binding of BimEL to $\mathrm{Mcl}-1$. This was followed, during incubation at $37^{\circ} \mathrm{C}$ after the heat treatment, by the release of BimEL due in part to displacement with newly synthesized Noxa. The reassociation of Noxa with $\mathrm{Mcl}-1$ seen at $6 \mathrm{~h}$ after heat treatment would inhibit the ability of the remaining $\mathrm{Mcl}-1$ to prevent Bax/Bak activation or, by preventing sequestration of Bim, allow Bim to directly activate Bax/Bak. Heat shock also caused increased synthesis of Noxa in the Hsp70-expressing cells; however, as Mcl-1 levels were maintained, there was sufficient $\mathrm{Mcl}-1$ to inhibit Noxa and Bim. We were unable to demonstrate a direct interaction between Bim and either Bax or Bak, similar to the findings of Willis et al. ${ }^{36}$ and so we cannot conclude that the declining levels of $\mathrm{Mcl}-1$ result in an increased pool of free Bim able to directly activate Bax and Bak. However, our results do show that heat shock leads to the loss of $\mathrm{Mcl}-1$ through a combination of reduced synthesis, inactivation by Mule binding and ubiquitination as well as caspase cleavage and that overexpression of Hsp70 prevents each of these effects resulting in Mcl-1 stabilization. The overall outcome is that Bax is not activated in cells expressing Hsp70. It should be noted that our results do not rule out the potential contribution of Bad and the Badinteracting proteins $\mathrm{Bcl}-2, \mathrm{Bcl}-\mathrm{xL}$ and $\mathrm{Bcl}-\mathrm{w}$ in heat-induced apoptosis.

Noxa is unique among $\mathrm{BH} 3-$ only proteins in its high degree of specificity for Mcl-1 and A1. ${ }^{37}$ Overexpression of Noxa is not an efficient inducer of cell death unless Bad, which binds to $\mathrm{Bcl}-2, \mathrm{Bcl}-\mathrm{xL}$ and $\mathrm{Bcl}-\mathrm{w}$, is also overexpressed. In leukemia cells, the sequestered Bim can be released by a combination of $\mathrm{ABT}-737$, a BH3 mimetic that binds $\mathrm{Bcl}-2, \mathrm{Bcl}-\mathrm{xL}$ and $\mathrm{Bcl}-\mathrm{w}$, and treatments that lead to $\mathrm{Mcl}-1$ downregulation, as ABT-737 does not inhibit Mcl-1. ${ }^{38}$ Pharmacological modulators of Mcl-1 stability include proteasomal inhibitors such as bortezomib, the cyclin-dependent kinase inhibitor seliciclib and the synthetic retinoid $N$-(4-hydroxyphenyl) retinamide. ${ }^{39-41}$ Our results suggest that $A B T-737$ in combination with hyperthermia would provide an effective means to target all of the antiapoptotic Bcl-2 family proteins and promote apoptosis in tumor cells. However, our results also caution that the effectiveness of this regime would be limited in cells that overexpress heat-shock proteins, as often occurs in tumor cells. ${ }^{31}$ Therefore, targeting heat-shock protein function in tumor cells may also be required.

\section{Materials and Methods}

Cells and treatments. The human acute lymphoblastic T-cell line, PEER, with tetracycline-regulated expression of Hsp70 (PErTA70) has been described. ${ }^{23}$ For the generation of Noxa shRNA cell lines, PEER cells were transfected with the pSUPER plasmid (obtained from Dr. Reuven Agami) containing inserts targeting human Noxa mRNA (NM021127.2: AGAAGTAATTATTGACACA) or an irrelevant sequence that does not target any human gene product (TTCTCCGAA CGTGTCACGT) as a control. The plasmid was modified to include the mRFP gene under the control of the $\mathrm{CMV}$ promoter to assist in stable clone selection. Cells were maintained at $37^{\circ} \mathrm{C}$ in a $5 \% \mathrm{CO}_{2}$ humidified incubator in RPMI medium with $10 \%$ fetal bovine serum (Invitrogen Inc., Burlington, Canada). Cells were heat shocked by the immersion of log-phase cells in a circulating water bath maintained at $43 \pm 0.1^{\circ} \mathrm{C}$. After the hyperthermic treatments, the cells were either diluted in fresh $37^{\circ} \mathrm{C}$ medium, transferred to a culture flask and returned to the $37^{\circ} \mathrm{C}$ incubator or placed directly on ice and washed in cold phosphate-buffered saline (PBS) for collection. For UV exposure, cells suspended in PBS were exposed to $40 \mathrm{~kJ} / \mathrm{m}^{2}$ in 
an open petri dish using a UV cross-linker chamber (Ultra-LUM; Fischer Scientific, Ottawa, Canada). After exposure, the cells were diluted to $0.5 \times 10^{6} \mathrm{cell} / \mathrm{s} / \mathrm{ml}$ with fresh medium and incubated at $37^{\circ} \mathrm{C}$ for $6 \mathrm{~h}$ before collection. Control cells were treated in the same way except that they were not exposed to UV light. For proteasomal inhibition studies, cells were pretreated with $10 \mu \mathrm{M}$ MG132 (BIOMOL International, Plymouth Meeting, PA, USA) for $30 \mathrm{~min}$ before exposure to hyperthermia. Following the heat-shock treatment, cells were pelleted and resuspended in fresh medium containing MG132 and incubated at $37^{\circ} \mathrm{C}$ until collection. Mcl-1 protein turnover was measured by treating cells with cycloheximide $(200 \mu \mathrm{g} / \mathrm{ml})$ in the presence of the pan-caspase inhibitor $\operatorname{ZVAD}(10 \mu \mathrm{M})$ and incubation at $37^{\circ} \mathrm{C}$ for 3 and $6 \mathrm{~h}$.

Cell viability assays. Caspase activity was evaluated by measuring DEVDase activity in cell extracts using the substrate Ac-DEVD-AMC ( $N$-acetylAsp-Glu-Val-Asp-(7-amino-4-methylcoumarin); BIOMOL International) as described earlier. $^{6}$ The relative fluorescence units of AMC released per min per $\mu \mathrm{g}$ protein were calculated for each sample and plotted relative to the maximum value. Viable/ apoptotic cell counts were determined by assessing plasma membrane integrity and nuclear morphology using plasma membrane-permeant (acridine orange) and -impermeant (ethidium bromide) DNA-intercalating dyes. ${ }^{22}$ Long-term viability was determined by measuring the reduction of Alamar Blue as described earlier. ${ }^{42}$ Briefly, control and treated cells were seeded at a concentration of $2.5 \times 10^{5} \mathrm{cells} / \mathrm{ml}$ in 12-well microplates and incubated at $37^{\circ} \mathrm{C}$. At daily intervals, cell suspensions (100 $\mu$ in triplicate) were seeded into a 96-well plate with $100 \mu$ l of media containing $50 \mu \mathrm{M}$ resazurin (Sigma-Aldrich, Oakville, Canada) and incubated at $37^{\circ} \mathrm{C}$ for $5 \mathrm{~h}$. Fluorescence generated from resazurin reduction was measured in a microplate fluorescence reader (Ex516/20, Em590/35). Viability is expressed as a percentage of the control values measured after 3 days of culture.

Immunoprecipitation and immunoblotting. Immunoprecipitation and immunoblotting experiments were performed as described earlier. ${ }^{6}$ Briefly, for IP, cells were lysed in 2\% 3-[(3-cholamidopropyl)dimethylammonio]-1-propane sulfonate hydrate (CHAPS) IP lysis buffer $(20 \mathrm{mM}$ Tris- $\mathrm{HCl}(\mathrm{pH} 7.4), 137 \mathrm{mM}$ $\mathrm{NaCl}, 2 \mathrm{mM}$ EDTA, 2\% CHAPS) containing phosphatase and protease inhibitors $(2 \mu \mathrm{g} / \mathrm{ml}$ each of pepstatin, leupeptin and aprotinin) and phosphatase inhibitors ( $50 \mathrm{mM}$ sodium fluoride and $1 \mathrm{mM}$ sodium vanadate) for $30 \mathrm{~min}$ on ice. Lysates (300 $\mu \mathrm{g}$ protein) were incubated overnight at $4^{\circ} \mathrm{C}$ on a rotator with $1 \mu \mathrm{g}$ of anti-Mcl-1 (sc-819: Santa Cruz Biotechnology, Santa Cruz, CA, USA) or anti-Bax (N20: Santa Cruz Biotechnology) antibody. The N20 Bax antibody is conformation specific and immunoprecipitates only active Bax. Immunoprecipitates were collected by the addition of $10 \mu \mathrm{l}$ of washed protein A agarose beads (EZview Affinity Gel; SigmaAldrich) and incubation for $1 \mathrm{~h}$ at $4{ }^{\circ} \mathrm{C}$ on a rotator. Complexes were collected by centrifugation and washed four times with lysis buffer. Finally, the pelleted beads were resuspended in $1 \times$ sodium dodecyl sulfate (SDS) sample buffer ( $50 \mathrm{mM}$ Tris$\mathrm{HCl}(\mathrm{pH} 6.8), 2 \% \mathrm{SDS}, 10 \%$ glycerol, $5 \% \beta$-mercaptoethanol) and heated at $95^{\circ} \mathrm{C}$ for $5 \mathrm{~min}$ for analysis by SDS-polyacrylamide gel electrophoresis and western blotting. The specificity of the co-IP results was tested by performing the Mcl-1 IPs in the presence of a fivefold excess of the Mcl-1 peptide used to generate the antibody (sc-819P: Santa Cruz Biotechnology) or an irrelevant peptide (Bax N20 peptide, Sc-493P: Santa Cruz Biotechnology). Immunoprecipitation of denatured Mcl-1 was performed as above except that the cells were lysed in denaturing lysis buffer (40 mM Tris, $1 \%$ SDS, $1 \% \beta$-mercaptoethanol, $100 \mathrm{mM} \mathrm{DTT}$ ), sonicated and heated to $95^{\circ} \mathrm{C}$ for $10 \mathrm{~min}$. The lysates were cleared by centrifugation, diluted $1: 10$ with RIPA buffer ( $150 \mathrm{mM} \mathrm{NaCl}, 1 \%$ sodium deoxycholate, $1 \%$ Triton X-100, $10 \mathrm{mM}$ Tris (pH 7.4), 0.1\% SDS, $1 \mathrm{mM}$ PMSF) and used for IP with Mcl-1 antibody. The following antibodies were used in western blotting experiments: Actin (ACTN05: NeoMarkers, Fremont, CA, USA), Bak (556396: BD Biosciences, Mississauga, Canada), Bax (N20: Santa Cruz Biotechnology), Bim (AAP-330: Stressgen/Assay Designs, Ann Arbor, MI, USA), Caspase-3 (SA-320-0100: BIOMOL International), Hsc70 (1B5: Stressgen), Hsp70 (C92F3A-5: Stressgen), Mcl-1 (sc-819: Santa Cruz Biotechnology), Mule (aka Lasu1/Ureb1, A300-486A: Bethyl Laboratories, Montgomery, TX, USA), Noxa (114C307.1: Alexis Biochemicals, San Diego, CA, USA) and Ubiquitin (P4D1: Cell Signaling Technology, Danvers, MA, USA). For the detection of Noxa, we used 0.2- $\mu$ m PVDF membranes (Immobilon PSQ) instead of 0.45 to enhance binding of low-molecular-weight proteins and performed the incubations in Hikari signal enhancer solution (Nacalai USA Inc., San Diego, CA, USA). Chemical cross-linking with EGS before western blotting to assess Bax oligomerization was performed as described. ${ }^{6}$
Acknowledgements. This study was supported by the Natural Science and Engineering Research Council of Canada.

1. Taylor RC, Cullen SP, Martin SJ. Apoptosis: controlled demolition at the cellular level. Nat Rev Mol Cell Biol 2008; 9: 231-241.

2. Antonsson B, Montessuit S, Sanchez B, Martinou JC. Bax is present as a high molecular weight oligomer/complex in the mitochondrial membrane of apoptotic cells. J Biol Chem 2001; 276: 11615-11623.

3. Leber B, Lin J, Andrews DW. Embedded together: the life and death consequences of interaction of the Bcl-2 family with membranes. Apoptosis 2007; 12: 897-911.

4. Adams JM, Cory S. The Bcl-2 apoptotic switch in cancer development and therapy. Oncogene 2007; 26: 1324-1337.

5. Chipuk JE, Green DR. How do BCL-2 proteins induce mitochondrial outer membrane permeabilization? Trends Cell Biol 2008; 18: 157-164.

6. Stankiewicz AR, Lachapelle G, Foo CP, Radicioni SM, Mosser DD. Hsp70 inhibits heatinduced apoptosis upstream of mitochondria by preventing Bax translocation. $\mathrm{J}$ Biol Chem 2005; 280: 38729-38739.

7. Pagliari LJ, Kuwana T, Bonzon C, Newmeyer DD, Tu S, Beere HM et al. The multidomain proapoptotic molecules Bax and Bak are directly activated by heat. Proc Natl Acad Sci USA 2005; 102: 17975-17980.

8. Opferman JT. Unraveling MCL-1 degradation. Cell Death Differ 2006; 13: 1260-1262.

9. Derenne S, Monia B, Dean NM, Taylor JK, Rapp MJ, Harousseau JL et al. Antisense strategy shows that $\mathrm{Mcl}-1$ rather than $\mathrm{Bcl}-2$ or $\mathrm{Bcl}-\mathrm{x}(\mathrm{L})$ is an essential survival protein of human myeloma cells. Blood 2002; 100: 194-199.

10. Michels J, Johnson PW, Packham G. Mcl-1. Int J Biochem Cell Biol 2005; 37: 267-271.

11. Bae J, Leo CP, Hsu SY, Hsueh AJ. MCL-1S, a splicing variant of the antiapoptotic BCL-2 family member $\mathrm{MCL}-1$, encodes a proapoptotic protein possessing only the $\mathrm{BH} 3$ domain. J Biol Chem 2000; 275: 25255-25261.

12. Nechushtan A, Smith CL, Lamensdorf I, Yoon SH, Youle RJ. Bax and Bak coalesce into novel mitochondria-associated clusters during apoptosis. J Cell Biol 2001; 153: 1265-1276.

13. Zhong Q, Gao W, Du F, Wang X. Mule/ARF-BP1, a BH3-only E3 ubiquitin ligase, catalyzes the polyubiquitination of Mcl-1 and regulates apoptosis. Cell 2005; 121: 1085-1095.

14. Maurer U, Charvet C, Wagman AS, Dejardin E, Green DR. Glycogen synthase kinase-3 regulates mitochondrial outer membrane permeabilization and apoptosis by destabilization of MCL-1. Mol Cell 2006; 21: 749-760.

15. Inoshita S, Takeda K, Hatai T, Terada Y, Sano M, Hata J et al. Phosphorylation and inactivation of myeloid cell leukemia 1 by JNK in response to oxidative stress. J Biol Chem 2002; 277: 43730-43734.

16. Han J, Goldstein LA, Gastman BR, Froelich CJ, Yin XM, Rabinowich H. Degradation of $\mathrm{Mcl}-1$ by granzyme B: implications for Bim-mediated mitochondrial apoptotic events. J Biol Chem 2004; 279: 22020-22029.

17. Willis SN, Chen L, Dewson G, Wei A, Naik E, Fletcher Jl et al. Proapoptotic Bak is sequestered by $\mathrm{Mcl}-1$ and $\mathrm{Bcl}-\mathrm{xL}$, but not $\mathrm{Bcl}-2$, until displaced by $\mathrm{BH} 3-$ only proteins. Genes Dev 2005; 19: 1294-1305.

18. Czabotar PE, Lee EF, van Delft MF, Day CL, Smith BJ, Huang DC et al. Structural insights into the degradation of Mcl-1 induced by BH3 domains. Proc Natl Acad Sci USA 2007; 104: 6217-6222.

19. Han J, Goldstein LA, Hou W, Rabinowich H. Functional linkage between NOXA and Bim in mitochondrial apoptotic events. J Biol Chem 2007; 282: 16223-16231.

20. Warr MR, Acoca S, Liu Z, Germain M, Watson M, Blanchette $M$ et al. BH3-ligand regulates access of MCL-1 to its E3 ligase. FEBS Lett 2005; 579: 5603-5608.

21. Mosser DD, Martin LH. Induced thermotolerance to apoptosis in a human T lymphocyte cell line. J Cell Physiol 1992; 151: 561-570.

22. Mosser DD, Caron AW, Bourget L, Denis-Larose C, Massie B. Role of the human heat shock protein hsp70 in protection against stress-induced apoptosis. Mol Cell Biol 1997; 17: 5317-5327.

23. Mosser DD, Caron AW, Bourget L, Meriin AB, Sherman MY, Morimoto Rl et al. The chaperone function of hsp70 is required for protection against stress-induced apoptosis. Mol Cell Biol 2000; 20: 7146-7159.

24. Naik E, Michalak EM, Villunger A, Adams JM, Strasser A. Ultraviolet radiation triggers apoptosis of fibroblasts and skin keratinocytes mainly via the BH3-only protein Noxa. J Cell Biol 2007; 176: 415-424.

25. Clohessy JG, Zhuang J, Brady HJ. Characterisation of Mcl-1 cleavage during apoptosis of haematopoietic cells. Br J Haematol 2004; 125: 655-665.

26. Gabai VL, Meriin AB, Mosser DD, Caron AW, Rits S, Shifrin VI et al. Hsp70 prevents activation of stress kinases. A novel pathway of cellular thermotolerance. J Biol Chem 1997; 272: 18033-18037.

27. Meller R, Cameron JA, Torrey DJ, Clayton CE, Ordonez AN, Henshall DC et al. Rapid degradation of Bim by the ubiquitin-proteasome pathway mediates short-term ischemic tolerance in cultured neurons. J Biol Chem 2006; 281: 7429-7436.

28. Domina AM, Vrana JA, Gregory MA, Hann SR, Craig RW. MCL1 is phosphorylated in the PEST region and stabilized upon ERK activation in viable cells, and at additional sites with cytotoxic okadaic acid or taxol. Oncogene 2004; 23: 5301-5315.

29. Esser C, Alberti S, Hohfeld J. Cooperation of molecular chaperones with the ubiquitin/ proteasome system. Biochim Biophys Acta 2004; 1695: 171-188. 
30. Liu RY, Li X, Li L, Li GC. Expression of human hsp70 in rat fibroblasts enhances cell survival and facilitates recovery from translational and transcriptional inhibition following heat shock. Cancer Res 1992; 52: 3667-3673.

31. Mosser DD, Morimoto RI. Molecular chaperones and the stress of oncogenesis. Oncogene 2004; 23: 2907-2918.

32. Morimoto RI. Proteotoxic stress and inducible chaperone networks in neurodegenerative disease and aging. Genes Dev 2008; 22: 1427-1438.

33. Cuconati A, Mukherjee C, Perez D, White E. DNA damage response and MCL-1 destruction initiate apoptosis in adenovirus-infected cells. Genes Dev 2003; 17 2922-2932.

34. Nijhawan D, Fang M, Traer E, Zhong Q, Gao W, Du F et al. Elimination of Mcl-1 is required for the initiation of apoptosis following ultraviolet irradiation. Genes Dev 2003; 17 1475-1486.

35. Gao M, Karin M. Regulating the regulators: control of protein ubiquitination and ubiquitinlike modifications by extracellular stimuli. Mol Cell 2005; 19: 581-593.

36. Willis SN, Fletcher JI, Kaufmann T, van Delft MF, Chen L, Czabotar PE et al. Apoptosis initiated when BH3 ligands engage multiple Bcl-2 homologs, not Bax or Bak. Science 2007; 315: 856-859.
37. Chen L, Willis SN, Wei A, Smith BJ, Fletcher JI, Hinds MG et al. Differential targeting of prosurvival $\mathrm{Bcl}-2$ proteins by their $\mathrm{BH} 3$-only ligands allows complementary apoptotic function. Mol Cell 2005; 17: 393-403.

38. Certo M, Del Gaizo Moore V, Nishino M, Wei G, Korsmeyer S, Armstrong SA et al. Mitochondria primed by death signals determine cellular addiction to antiapoptotic BCL-2 family members. Cancer Cell 2006; 9: 351-365.

39. Podar K, Gouill SL, Zhang J, Opferman JT, Zorn E, Tai YT et al. A pivotal role for Mcl-1 in Bortezomib-induced apoptosis. Oncogene 2008; 27: 721-731.

40. MacCallum DE, Melville J, Frame S, Watt K, Anderson S, Gianella-Borradori A et al. Seliciclib (CYC202, R-Roscovitine) induces cell death in multiple myeloma cells by inhibition of RNA polymerase II-dependent transcription and down-regulation of Mcl-1. Cancer Res 2005; 65: 5399-5407.

41. Kang MH, Wan Z, Kang YH, Sposto R, Reynolds CP. Mechanism of synergy of $\mathrm{N}$-(4-hydroxyphenyl)retinamide and ABT-737 in acute lymphoblastic leukemia cell lines: Mcl-1 inactivation. J Natl Cancer Inst 2008; 100: 580-595.

42. Lachapelle G, Radicioni SM, Stankiewicz AR, Mosser DD. Acute acidification or amiloride treatment suppresses the ability of Hsp70 to inhibit heat-induced apoptosis. Apoptosis 2007; 12: $1479-1488$ 